\title{
Mentoring Process a Stimulus for Professional Development of Primary School Teachers in Punjab, Pakistan
}

\author{
Muhammad Akhlaq \\ PhD Scholar, Department of Education, International Islamic University, Islamabad \\ mmakhlaq2009@gmail.com \\ Muhammad Zafar Iqbal \\ Teaching/Research Associate, Department of Education, International Islamic University, Islamabad \\ Zafar.phdedu57@iiu.edu.pk \\ Prof. Dr. N. B. Jumani \\ Professor, Department of Education, International Islamic University, Islamabad
}

\section{Dr. Saeed ul Hassan Chishti}

Project Director, IPD, International Islamic University, Islamabad

Doi:10.5901/mjss.2015.v6n3s1p146

\section{Abstract}

This paper explores the effects of mentoring on the professional development of Primary School Teachers (PSTs) in Punjab province, Pakistan. The key objectives of the study include: to study the mentoring process started in Punjab province Pakistan for PSTs, to study the effects of mentoring process on the professional development of PSTs. The population of the study was 47988 PSTs and 1370 District Teachers Educators (DTEs) from the twelve districts of Punjab province. The sample was comprised of 381 PSTs and 302 DTEs from the 12 districts of the province. Quantitative data was collected through specifically designed questionnaires. The data was analyzed by using Mean Score, Chi-Square was used to compare the group frequencies and t-test was used to see the significance difference between the means of both groups. Qualitative data was collected through interviews and analyzed by using NVIVO software version 10. Majority of the PSTS and DTEs agreed that mentoring process helped them out in decreasing the professional stress and helped out in covering the backlogs of unseen days in an educational year. Both groups of respondents were agreed that mentoring process was not helpful in achieving the pre-set targets. Mentoring process may be designed in such a way that it should help the PSTs in managing the activities of absent days. Mentoring process should be designed to help out the PSTs in managing the teaching activities in a realistic ways. Directorate of Staff Development (DSD) should evolve a inclusive mentoring model for implementation of Continuous Professional Development (CPD) activities in different areas of professional development of Primary School Teachers with reference to research, training, monitoring and evaluation.

Keywords: Mentoring; Primary School Teachers; District Teacher Educators; Professional Development

\section{Introduction}

Mentoring has been emerged as a key source for the professional development of doctors, managers, engineers, lawyers and teachers. At all levels of teaching mentoring should be an integral part of professional development of teachers to enhance their professional skills (Johnson, 2007). Quality of education at all level depends upon the skills and competencies of the teachers. Mentoring programmes should focus to improve the classroom practices of teachers and to increase the learning outcomes of students' (Murphy et, al. 2005). Generally, mentoring is linked to the real needs of teachers which are identified through research achieved through regular mentoring under the umbrella of professional development programs (Allen \& Day 2002).

Typically mentoring refers a relationship between a less experienced individual called a "mentee" and a more experienced individual known as a "mentor". Mentoring also refers an interaction between a more experienced person and less experienced person of same field or area of study where more skilled person helps, guides and encourages to 
less experienced persons through counseling and coaching to fulfill their professional needs. Mentoring relationships may exist in formal, informal, long-term, short-term basis, face-to- face conversation basis or electronically (Kasprisin etal, 2003; Packard, 2002; Donaldson, et.al 2005). Traditionally, mentoring is sought as a dyadic, face-to-face, long-term relationship between a supervisory adult and beginner students that fosters the mentee's academic, or personal and professional development (Donaldson, Ensher, \& Grant-Vallone, 2000). A supportive learning relationship between a caring individual who shares experience and knowledge with other individuals who are willing to develop their professional skills. Mentoring a supportive learning relationship between a caring individual who shares knowledge, experience, and wisdom with individuals who are willing to develop their professional qualities and partnership skills. Mentoring process provides a path for professional growth (Fanure, 2000). A two way mutual relationship, particularly in the employment sector. Mentoring process includes the various phases of the application for cognitive and professional developmental of the mentees (Bey and Holmes, 1992). Mentoring process helped the new employees to learn about organizational culture and to function efficiently within the context of the organization (Huwe, 2003).

\section{Benefits of Mentoring}

Benefits of mentoring appeared in previous literature include; professional growth, practical training, direct purposeful experiences and training in practical matters usually conducted in classrooms, workshops or in training institutions (Darwin, 2000; Foster \& Clark 2011). Mentoring involves psychosocial and professional development functions (Lewis, 2004). Mentor plays role as a counselor, friend, coach or sponsor for the psychosocial development of the mentees (Noe, 2008; Ragins, 2009 \& McFarlin, 2010). Some educationists have visualized the role modeling as third function of mentoring embedded within psychosocial functions (Donaldson, 2005, Williams, 2008). The breadth and depth of mentoring and professional development may vary in different contexts (Little, 2010). In the context of professional development of teachers, mentoring is an arrangement in which teachers are provided professional support and consultancy by experienced teachers i.e. mentors on different tasks and problems. Odell \& Huling (2010) identified the following should must exist the following relationship in mentoring process:

- Mentoring programs should be collaboratively planned, implemented, monitored and be evaluated by the key stakeholders.

- Mentoring must have receptive to the evolving needs of both mentor and mentees.

- In mentoring program it should be focused on the mentee desires to become skilled person through mentoring process.

- Mentoring program should contribute in improving the culture of the organization.

- Mentoring program should assist the mentees to teach in accordance with recognized professional standards for teaching and learning.

In the context of the professional development, mentoring is a well-known activity which apprehends with the practitioners in a work-based practice for the improvement of their skilfulness and understanding. Murray (2007) has highlighted that mentoring is a conscious pairing of more skilled person with a less experienced persons with the purpose to develop the professional knowledge and requisite competencies. Hall (2008) mentoring is an intentional relationship which focuses on self development of less experienced professional through dialogue and reflection. Daresh (2010) wrote that mentoring is an ongoing process in which an experienced professional provides support/ guidance to less experienced professionals.

\section{Mentoring in Punjab Province}

In Punjab professional development of Primary School Teachers have remained ignored for the past few decades. To bridge up the gaps, the Government Punjab initiated mentoring programs for the professional development of Primary School Teachers. Mentoring process was introduced in the Punjab in during (2007) for Continuous Professional Development (CPD) of PSTs to provide them the opportunities to enhance their professional skills (Govt. of Punjab, 2007). Researcher developed interest in this area and decided that it is imperative to study the effectiveness of the mentoring process already launched in Punjab Province. Thus, the researcher undertaken this exercise to measure the effectiveness of mentoring process provided through DTEs on the professional development of PSTs in Pakistan context. The key objectives to launch mentoring include: to ensure universal primary education campaign through 100\% enrollment at elementary level, 2) to ensure zero drops-out at elementary and secondary levels, 3) to ensure $100 \%$ attendance of the teachers and report daily absenteeism through e-mail to district and provincial authorities, 4 ) ranking of 
the schools, head teachers and teachers on the basis of student's academic results, 5) to ensure implementation of English medium scheme in 100\% of govt. schools, 6) to ensure monthly and periodic tests of students on prescribed formats for preparation and Board examinations, 7) to conduct census of schools, staff and facilities, and 8) to work jointly with head teachers and teachers for achievement of national targets (Govt. of Punjab, 2011).

As envisaged by the Government of Punjab (2010) the most important objective of mentoring program was to indentify and meet the professional needs of Primary School Teachers and to accelerate child leaning at elementary level. Changing these practices requires a long term relationship with the individual teacher, understanding of the learner and classroom context, joint planning and collective work with the teacher, and continuous support to the teacher (Glesser, 2009). The teacher mentoring and support cannot be separated from students learning. Mentoring program was initiated in 2007 under the umbrella of Directorate of Staff Development to fulfill the professional development needs of PSTs through network of DTEs. The District Teacher Educators are providing mentoring to the Primary School Teachers in the following eight areas:

Table 1: Mentoring Areas for Primary School Teachers in Punjab

\begin{tabular}{ccl}
\hline Sr. No & Area No & Name of Mentoring Area \\
\hline 1. & Area=1 & Taleemi Calendar \\
2. & Area $=2$ & Lesson Planning \\
3. & Area $=3$ & Activities Based Teaching and Learning \\
4. & Area $=4$ & Used of Support Material \\
5. & Area $=5$ & Interaction with Students \\
6. & Area $=6$ & Classroom Management \\
7. & Area $=7$ & Students Assessment \\
8. & Area $=8$ & Home Work (DTE Guide, 2011) \\
\hline
\end{tabular}

The above mentioned mentoring areas aimed to develop pedagogical skills in Primary School Teachers. The present study focused mentoring area-1 "Taleemi Calendar".

\section{Objectives of the Research}

1. To study the mentoring process already started for Primary School Teacher in Punjab Province.

2. To analyze the effects of mentoring process on the professional development of Primary School Teachers in Punjab Province.

\section{Research Questions}

Study was guided by following research questions:

1. To what extent the Taleemi Calendar is effective in mentoring process of the Primary School Teachers?

2. To what extent mentoring process helps the Primary School Teachers in managing teaching learning activities according to Taleemi calendar.

3. To what extent mentoring process helps out the Primary School Teachers in using Taleemi Calendar rigorously.

4. To what extent process of mentoring launched in Punjab Province facilitated the Primary School Teachers in achieving the pre-set targets.

\section{Hypotheses}

$\mathrm{H}_{1}$ Frequency of the opinions of the PSTs on mentoring process significantly contributes to manage teaching related activities according to Taleemi Calendar.

$\mathrm{H}_{\mathrm{o1}}$ Frequency of the opinions of the PSTs on mentoring process does not significantly contribute to manage teaching related activities according to Taleemi Calendar.

$\mathrm{H}_{2}$ Frequency of the opinions of the DTES on mentoring process significantly contributes to manage teaching related activities according to Taleemi Calendar.

$\mathrm{H}_{02}$ frequency of the opinions of the DTEs on mentoring process does not significantly contribute to manage teaching related activities according to Taleemi Calendar. 
$\mathrm{H}_{3}$ The mean opinion scores the PSTs and the DTEs on mentoring process differ significantly on the management of teaching related activities according to Taleemi Calendar.

$\mathrm{H}_{03}$ The mean opinion scores the PSTs and the DTEs on mentoring process does not differ significantly on the management of teaching activities according to Taleemi Calendar.

\section{Methodology}

The mixed method study was delimited to the following 12 districts of Punjab Province, Pakistan: District Attock, Sargodha, Muzffaarghar, M.B. Din, Okara, Mainwali, Gujarat, Shakhpura, Faisalabad, Rahimyarkhan, Rajanpur, and district Kasur. Mentoring Area-1 i.e "Taleemi Calendar" as focused. 1370 District Teachers Educators and 47988 Primary School Teachers formed the population of the study. Simple random sampling procedure was adopted for sample selection through a computer generated lists. The sample was comprised of 302 District Teachers Educators and 381 Primary School Teachers. Two questionnaires on five points Likert's scale were respectively developed for PSTs and DTEs. Data was collected personally and as well as through registered and electronic mail. Prior permission was sought to conduct interviews with the respondents. Content validity of the questionnaires were checked in discussion with experts of the same filed and interest. Cronbach alpha was also applied to calculate the reliability of the questionnaires. The value of alpha of both instruments was 0.86. Data was analyzed by calculating percentages and Mean Scores, Chisquare was also used to compare the group frequencies and t-test was used to see that if there was significant difference exits between the means of the both groups. The data collected through interviews of Primary School Teachers and District Teacher Educators was analyzed by using NVIVO version 10. The data collection process was completed in six months. Questionnaires were delivered personally to all two categories of respondents of the study. Keeping in the view of the availability of the respondents, researcher preferred to approach the respondents during May 2013before the summer vacations of hot regions of Punjab province. Although in interview similar questions were asked to mentees and mentors but each time different respondents replied subject matters of professional development. The different responses revealed different type of experiences, perceptions, and different point of views of on the existing mentoring process.

\section{Results}

Demographic information about the respondents is described below.

- Majority of the respondents were 40 years old. 163 (42.8\%) Primary School Teachers were male and 218 (57.2\%) female and 230 (76.2 \%) District Teacher Educators were male and 72 (23.8\%) were female. Majority of PSTs were graduates while majority of DTEs were master degree holders. Majority of Primary School Teachers were having professional qualifications B.Ed while most of District Teacher Educators were having M.Ed. degrees..

Table 3: Opinions of Primary School Teachers and District Teacher Educators about the effectiveness of Mentoring

\begin{tabular}{|c|c|c|c|c|c|c|c|c|c|}
\hline Sr.No & Statements & Respondents & SDA & DA & UD & A & SA & $\begin{array}{c}X^{2} \\
\text { Value }\end{array}$ & $p$-value \\
\hline \multirow[b]{2}{*}{1} & \multirow{2}{*}{$\begin{array}{l}\text { Mentoring process helps the mentees in } \\
\text { managing all the teaching activities according to } \\
\text { the Taleemi Calendar i.e. educational calendar. }\end{array}$} & PSTs $N=381$ & $\begin{array}{c}90 \\
(23.60 \%)\end{array}$ & $\begin{array}{c}72 \\
(18.9 \%)\end{array}$ & $\begin{array}{c}11 \\
(2.90 \%)\end{array}$ & $\begin{array}{c}109 \\
(28.60 \%)\end{array}$ & $\begin{array}{c}99 \\
(26.00 \%)\end{array}$ & 77.885 & 0.0001 \\
\hline & & DTEs N=302 & $\begin{array}{c}08 \\
(2.60 \%)\end{array}$ & $\begin{array}{c}20 \\
(6.61 \%)\end{array}$ & $\begin{array}{c}8 \\
(2.60 \%)\end{array}$ & $\begin{array}{c}118 \\
(39.10 \%)\end{array}$ & $\begin{array}{c}148 \\
(49.00 \%)\end{array}$ & 299.921 & 0.0000 \\
\hline \multirow[b]{2}{*}{2} & \multirow{2}{*}{$\begin{array}{l}\text { Mentoring process helps the mentees in } \\
\text { managing the teaching activities for the whole } \\
\text { educational year in a realistic way. }\end{array}$} & PSTs N=381 & $\begin{array}{c}110 \\
(28.90 \% 0\end{array}$ & $\begin{array}{c}91 \\
(23.90 \%)\end{array}$ & 00 & $\begin{array}{c}102 \\
(26.80 \%)\end{array}$ & $\begin{array}{c}78 \\
(20.50 \%)\end{array}$ & 6.076 & 0.1080 \\
\hline & & DTEs N=302 & $\begin{array}{c}70 \\
(23.21 \%)\end{array}$ & $\begin{array}{c}85 \\
(28.10 \%)\end{array}$ & 00 & $\begin{array}{c}68 \\
(22.51 \%)\end{array}$ & $\begin{array}{c}79 \\
(26.20 \%)\end{array}$ & 2.503 & 0.475 \\
\hline \multirow{2}{*}{3} & \multirow{2}{*}{$\begin{array}{l}\text { Mentoring process helps the mentees in using } \\
\text { Taleemi Calendar rigorously. }\end{array}$} & PSTs N=381 & $\begin{array}{c}65 \\
(17.11 \%)\end{array}$ & $\begin{array}{c}91 \\
(23.90 \%)\end{array}$ & $\begin{array}{c}11 \\
(2.910 \%)\end{array}$ & $\begin{array}{c}98 \\
(25.71 \%)\end{array}$ & $\begin{array}{c}116 \\
(30.41 \%)\end{array}$ & 87.333 & 0.000 \\
\hline & & DTEs N=302 & $\begin{array}{c}65 \\
(21.50 \%) \\
\end{array}$ & $\begin{array}{c}77 \\
(25.50 \%)\end{array}$ & $\begin{array}{c}11 \\
(3.60 \%)\end{array}$ & $\begin{array}{c}70 \\
(23.20 \%)\end{array}$ & $\begin{array}{c}79 \\
(26.20 \%) \\
\end{array}$ & 52.570 & 0.000 \\
\hline \multirow{2}{*}{4} & \multirow{2}{*}{$\begin{array}{l}\text { Mentoring process helps in covering the } \\
\text { backlogs of unseen days of an educational } \\
\text { year. }\end{array}$} & PSTs N=381 & $\begin{array}{c}63 \\
(16.50 \%)\end{array}$ & $\begin{array}{c}77 \\
(20.20 \%)\end{array}$ & $\begin{array}{c}07 \\
(1.80 \%)\end{array}$ & $\begin{array}{c}131 \\
(34.40 \%)\end{array}$ & $\begin{array}{c}103 \\
(27.00 \%)\end{array}$ & 113.974 & 0.0000 \\
\hline & & DTEs N=302 & $\begin{array}{c}31 \\
(10.30 \%)\end{array}$ & $\begin{array}{c}43 \\
(14.20 \%)\end{array}$ & $\begin{array}{c}09 \\
(3.00 \%)\end{array}$ & $\begin{array}{c}122 \\
(40.40 \%) \\
\end{array}$ & $\begin{array}{c}97 \\
(32.10 \%)\end{array}$ & 148.066 & 0.0001 \\
\hline \multirow{2}{*}{5} & \multirow{2}{*}{$\begin{array}{l}\text { Mentoring process helps to achieve the pre-set } \\
\text { targets well before time. }\end{array}$} & PSTs N=381 & $\begin{array}{c}98 \\
(25.70 \%)\end{array}$ & $\begin{array}{c}69 \\
(18.10 \%)\end{array}$ & $\begin{array}{c}05 \\
(1.30 \%)\end{array}$ & $\begin{array}{c}107 \\
(28.10 \%)\end{array}$ & $\begin{array}{c}102 \\
(26.80 \%)\end{array}$ & 94.630 & 0.0000 \\
\hline & & DTEs $N=302$ & $\begin{array}{c}71 \\
(23.50 \%)\end{array}$ & $\begin{array}{c}61 \\
(20.20 \%)\end{array}$ & 00 & $\begin{array}{c}75 \\
(24.80 \%)\end{array}$ & $\begin{array}{c}95 \\
(31.50 \%)\end{array}$ & 4.384 & 0.2230 \\
\hline
\end{tabular}




\begin{tabular}{|c|c|c|c|c|c|c|c|c|c|}
\hline 6 & $\begin{array}{l}\text { Mentoring process helps the mentees in } \\
\text { managing the leaves and absent days of an } \\
\text { educational year. }\end{array}$ & $\begin{array}{l}\text { PSTs } N=381 \\
\text { DTEs } N=302\end{array}$ & $\begin{array}{c}98 \\
(25.70 \%) \\
61 \\
(20.20 \%) \\
\end{array}$ & $\begin{array}{c}107 \\
(28.10 \%) \\
68 \\
(22.50 \%) \\
\end{array}$ & 00 & $\begin{array}{c}95 \\
(24.90 \%) \\
89 \\
(29.50 \%) \\
\end{array}$ & $\begin{array}{c}81 \\
(21.30 \%) \\
84 \\
(27.80 \%) \\
\end{array}$ & 3.661 & 0.300 \\
\hline \multirow[t]{2}{*}{7} & \multirow{2}{*}{$\begin{array}{l}\text { Mentoring process provides regular feedback } \\
\text { that contributes towards professional } \\
\text { development of Primary School Teachers. }\end{array}$} & PSTs N=381 & $\begin{array}{c}71 \\
(18.6 \%)\end{array}$ & $\begin{array}{c}98 \\
(25.70 \%)\end{array}$ & 00 & $\begin{array}{c}109 \\
(28.60 \%)\end{array}$ & $\begin{array}{c}103 \\
(27.00 \%)\end{array}$ & 8.869 & 0.031 \\
\hline & & DTEs N=302 & $\begin{array}{c}54 \\
(17.90 \%)\end{array}$ & $\begin{array}{c}71 \\
(23.50 \%)\end{array}$ & 00 & $\begin{array}{c}102 \\
(33.80 \%)\end{array}$ & $\begin{array}{c}102 \\
(33.80 \%)\end{array}$ & 15.695 & 0.001 \\
\hline \multirow[b]{2}{*}{8} & \multirow{2}{*}{$\begin{array}{l}\text { Mentoring process helps to decrease the } \\
\text { professional stress of the Primary School } \\
\text { Teachers. }\end{array}$} & PSTs N=381 & $\begin{array}{c}97 \\
(25.50 \%)\end{array}$ & $\begin{array}{c}81 \\
(21.30 \%)\end{array}$ & 00 & $\begin{array}{c}89 \\
(23.40 \%)\end{array}$ & $\begin{array}{c}114 \\
(29.90 \%)\end{array}$ & 6.265 & 0.099 \\
\hline & & DTEs N=302 & $\begin{array}{c}84 \\
(27.80 \%)\end{array}$ & $\begin{array}{c}75 \\
(24.80 \%)\end{array}$ & $\begin{array}{c}05 \\
(1.70 \%)\end{array}$ & $\begin{array}{c}73 \\
(24.20 \%)\end{array}$ & $\begin{array}{c}65 \\
(21.50 \%)\end{array}$ & 66.543 & 0.000 \\
\hline
\end{tabular}

1. Most of Primary School Teachers were agreed that mentoring process helped them in managing all the teaching activities according to the Taleemi Calendar. The value of $X^{2}$ was 77.8850 that was significant at $a=$ 0.001 level of significance indicates that there was huge difference in the responses of PSTs on the management of teaching activities according to the Taleemi Calendar. $\mathrm{H}_{01}$ i.e. "frequency of the opinions of the Primary School Teachers mentoring process does not significantly contribute to manage all the teaching related activities according to Taleemi Calendar" was rejected. Majority of the District Teacher Educators were agreed that mentoring process helped the mentees in managing all the teaching activities according to Taleemi Calendar i.e. educational calendar. The calculated value of $X^{2}$ was 299.9210 which was significant at $a=0.001$ level of significance due to uncertain value in the responses of District Teacher Educators. This showed that there was high difference in the opinions of District Teacher Educators which is highly divided with a tilt towards strongly agreement. Hence, the Null Hypothesis $\mathrm{H}_{02}$ "frequency of the opinions of the District Teacher Educators on mentoring process does not significantly contribute to manage teaching related activities according to Taleemi Calendar" was rejected. Therefore, it was concluded that mentoring process helped the mentees in managing the teaching activities according to Taleemi Calendar.

2. Majority of the Primary School Teachers disagreed that mentoring process did not help the mentees in using Taleemi Calendar rigorously. The calculated value of $x^{2}$ was 6.0760 which was not-significant at $\alpha=0.05$ level of significance. The Null Hypothesis $\mathrm{H}_{01}$ that frequency of the opinions of the Primary School Teachers mentoring process does not significantly contribute to manage teaching related activities according to Taleemi Calendar was not rejected. The calculated data showed that most of District Teacher Educators disagreed with that mentoring process did not help the mentees in using Taleemi Calendar rigorously. The value of $X^{2}$ was 2.503 which was not-significant at $\alpha=0.05$ levels. This indicated that there was no difference in the opinions of District Teacher Educators on the management of teaching activities in a realistic way. Hence, the Null Hypothesis $\mathrm{H}_{02}$ i.e. "frequency of the opinions of the District Teacher Educators on mentoring process does not significantly contribute to manage teaching related activities according to Taleemi Calendar" was not rejected. Hence, it is concluded in the opinions of PSTs and DTEs that mentoring process did not help the teachers in managing their teaching activities in a realistic way.

3. Majority of the Primary School Teachers respondents agreed that mentoring process helped the them in using Taleemi Calendar rigorously. The calculated value of $X^{2}$ was 87.3320 which was significant at $a=0.001$ level of significance. Thus, the Null Hypothesis $\mathrm{H}_{01}$ "frequency of the opinions of the Primary School Teachers mentoring process does not significantly contribute to manage teaching related activities according to Taleemi Calendar" was rejected. Similarly, most of the District Teacher Educators respondents agreed that mentoring process helped the mentees in using Taleemi Calendar rigorously. The value of $X^{2}$ was 52.570 which was overwhelmingly significant at $\alpha=0.001$ level of significance due to uncertain responses in the opinions of the District Teacher Educators. This revealed a high difference in the responses of District Teacher Educators on the rigorously uses of Taleemi Calendar. Hence, the Null Hypothesis $\mathrm{H}_{02}$ i.e. "frequency of the opinions of the District Teacher Educators on mentoring process does not significantly contribute to manage teaching related activities according to Taleemi Calendar" was rejected. Hence in the opinions of the mentors and the mentees i.e. Primary School Teachers and District Teacher Educators it is concluded that mentoring was helpful in rigorously using the Taleemi Calendar.

4. Majority of the Primary School Teachers respondents agreed that mentoring process helped them in covering the backlogs of unseen days of an educational year. The value of $x^{2}$ was 77.8850 which was overwhelmingly significant due to the uncertain responses in the opinions of Primary School Teachers. This depicted a high 
difference among the responses of Primary School Teachers that mentoring process helped in covering the backlogs of unseen days in an educational year and the Null Hypothesis $\mathrm{H}_{01}$ "frequency of the opinions of the Primary School Teachers mentoring process does not significantly contributes to manage teaching related activities according to Taleemi Calendar" was rejected. Most of the District Teacher Educators respondents agreed that mentoring process helped the Primary School Teachers in covering the backlogs of unseen days of an educational year. The calculated value of $X^{2}$ was 113.974 which was overwhelmingly significant that indicated the high difference in the responses of Primary School Teachers on mentoring process in helping the mentees to cover the backlogs of unseen days of an educational year. The Null Hypothesis $\mathrm{H}_{02}$ "frequency of the opinions of the District Teacher Educators on mentoring process does not significantly contribute to manage teaching related activities according to Taleemi Calendar" was rejected. So, it is concluded that mentoring process helped the Primary School Teachers in covering the backlogs of unseen days in an educational year.

5. Most of the Primary School Teachers respondents agreed that mentoring process helped them in achieving the pre-set targets well before time. The value of $X^{2} 94.630$ was significant at $a=0.001$ level of significance which indicated high differences in the responses of towards the strongly agreed with the statement. Thus, the Null Hypothesis $\mathrm{H}_{01}$ was rejected that frequency of the opinions of the Primary School Teachers mentoring process does not significantly contributes to manage teaching related activities according to Taleemi Calendar. Most of the District Teacher Educators respondents agreed that mentoring process helped the mentees in achieving the pre-set targets well before time. The calculated value of $X^{2}$ was 4.384 which was not-significant at $a=0.05$ level of significance. This reflected that there was equal difference in the responses of District Teacher Educators on the achievement of the pre-set targets well before time. The Null Hypothesis $\mathrm{H}_{02}$ was not rejected that frequency of the opinions of the District Teacher Educators on mentoring process does not significantly contribute to manage teaching related activities according to Taleemi Calendar. There was contradiction in the results of PSTs and DTEs opinions on the mentoring helps in achieving the pre-set targets well before time.

6. Most of the Primary School Teachers respondents agreed that mentoring process helped them in managing the leaves and absent days of an educational year. The calculated data showed that value of $x^{2}$ was 3.661 which was not-significant at $a=0.05$ level of significance. This showed the no difference in the opinions of Primary School Teachers on the management of leave or absent days of an educational year. Hence, the Null Hypothesis $\mathrm{H}_{01}$ "that frequency of the opinions of the Primary School Teachers mentoring process significantly contributes to manage teaching related activities according to Taleemi Calendar" was not rejected. Most of the District Teacher Educators respondents agreed that mentoring process helped the Primary School Teachers in managing leaves and absent days of an educational year. The calculated value of value of Chi-Square was 3.661 which was not-significant therefore, the Null Hypothesis $\mathrm{H}_{02}$ "frequency of the opinions of the District Teacher Educators on mentoring process does not significantly contribute to manage teaching related activities according to Taleemi Calendars" was not rejected.

7. Majority of the Primary School Teachers respondents disagreed that mentoring process did not provide regular feedback that contributed towards their professional development. The calculated value of $\chi 2$ was 8.869 which was not-significant at $\alpha=0.05$ level of significance. So, the Null Hypothesis $\mathrm{H}_{01}$ that "frequency of the opinions of the Primary School Teachers mentoring process does not significantly contribute to manage teaching related activities according to Taleemi Calendar" was not rejected. Most of the District Teacher Educators respondents agreed that mentoring process provided regular feedback that contributes towards professional development of Primary School Teachers. The calculated value of $x^{2} 15.695$ was highly significant at $\alpha=0.01$ level of significance. This indicated that there was difference in the responses of District Teacher Educators about the provision of regular feedback for the professional development of teachers. Hence, the Null Hypothesis $\mathrm{H}_{02}$ "frequency of the opinions of the District Teacher Educators on mentoring process does not significantly contribute to manage teaching related activities according to Taleemi Calendar" was rejected. There was contradiction in the opinions of PSTs and DTEs about the provision of regular feedback for the professional development of teachers.

8. Most of the Primary School Teachers respondents agreed that mentoring process helped them in decreasing their professional stress. The calculated value of $\chi^{2}$ was 6.265 which was not significant at $a=0.05$ level of significance. The Null Hypothesis $\mathrm{H}_{01}$ "that frequency of the opinions of the Primary School Teachers on mentoring process does not significantly contributes to manage teaching related activities according to Taleemi Calendar" was not rejected. Most of the District Teacher Educators respondents agreed that 
Mentoring process helps to decrease the professional stress of the Primary School Teachers. The calculated value of $x^{2}$ was 66.543 which was highly significant at $a=0.001$ level of significance. This showed that there was high difference in the opinions of District Teacher Educators about the professional stress of the teachers. The Null Hypothesis $\mathrm{H}_{02}$ was rejected that frequency of the opinions of the District Teacher Educators on mentoring process does not significantly contribute to manage teaching activities according to Taleemi Calendar. There was contradiction in the opinions of Primary School Teachers and Primary School Teachers about the provision that mentoring decreases the professional stress of the mentees.

Table 3: Opinions of the Primary School Teachers and District Teacher Educators on Taleemi Calendar

\begin{tabular}{|c|c|c|c|c|c|c|}
\hline Sr. No & Statement & Respondents & $\mathbf{x}$ & SD & $\begin{array}{c}\mathrm{t}- \\
\text { value }\end{array}$ & $\begin{array}{c}\mathrm{p}- \\
\text { value }\end{array}$ \\
\hline 1 & $\begin{array}{l}\text { Mentoring process helps the mentees in managing all the teaching activities } \\
\text { according to the Taleemi Calendar i.e. educational calendar. }\end{array}$ & $\begin{array}{l}\text { PSTs } N=381 \\
\text { DTEs } N=302\end{array}$ & $\begin{array}{l}2.57 \\
3.27\end{array}$ & $\begin{array}{l}1.528 \\
1.662\end{array}$ & 10.727 & 0.000 \\
\hline 2 & $\begin{array}{l}\text { Mentoring process helps the mentees in managing the teaching activities for the } \\
\text { whole educational year in a realistic way. }\end{array}$ & $\begin{array}{l}\text { PSTs } N=381 \\
\text { DTEs } N=302\end{array}$ & $\begin{array}{l}3.04 \\
3.00\end{array}$ & $\begin{array}{l}1.530 \\
1.577\end{array}$ & 1.175 & 0.241 \\
\hline 3 & Mentoring process helps the mentees in using Taleemi Calendar rigorously. & $\begin{array}{l}\text { PSTs } N=381 \\
\text { DTEs } N=302\end{array}$ & $\begin{array}{l}3.09 \\
3.07\end{array}$ & $\begin{array}{l}1.615 \\
1.548\end{array}$ & 1.832 & 0.067 \\
\hline 4 & $\begin{array}{l}\text { Mentoring process helps in covering the backlogs of unseen days of an } \\
\text { educational year. }\end{array}$ & $\begin{array}{l}\text { PSTs } N=381 \\
\text { DTEs } N=302\end{array}$ & $\begin{array}{l}4.55 \\
4.12\end{array}$ & & 3.193 & 0.001 \\
\hline 5 & Mentoring process helps to achieve the pre-set targets in well before time. & $\begin{array}{l}\text { PSTs } N=381 \\
\text { DTEs } N=302\end{array}$ & $\begin{array}{l}3.29 \\
3.07\end{array}$ & $\begin{array}{l}1.598 \\
1.629\end{array}$ & 0.386 & 0.700 \\
\hline 6 & $\begin{array}{l}\text { Mentoring process helps the mentees in managing the leaves and absent days } \\
\text { of an educational year. }\end{array}$ & $\begin{array}{l}\text { PSTs } N=381 \\
\text { DTEs } N=302\end{array}$ & $\begin{array}{l}2.90 \\
3.22\end{array}$ & $\begin{array}{l}1.550 \\
1.549\end{array}$ & 2.870 & 0.004 \\
\hline 7 & $\begin{array}{l}\text { Mentoring process provides regular feedback that contributes towards } \\
\text { professional development of Primary School Teachers. }\end{array}$ & $\begin{array}{l}\text { PSTs } N=381 \\
\text { DTEs } N=302\end{array}$ & $\begin{array}{l}3.56 \\
3.24\end{array}$ & $\begin{array}{l}1.429 \\
1.493\end{array}$ & 0.385 & 0.700 \\
\hline 8 & $\begin{array}{l}\text { Mentoring process helps in decreases the professional stress of the Primary } \\
\text { School Teachers. }\end{array}$ & $\begin{array}{l}\text { PSTs } N=381 \\
\text { DTEs } N=302\end{array}$ & $\begin{array}{l}2.96 \\
2.87\end{array}$ & $\begin{array}{l}1.560 \\
1.567\end{array}$ & 1.966 & 0.050 \\
\hline
\end{tabular}
$\mathrm{df}=681 \mathrm{t}$ at $0.05=1.96$

1. The difference between the mean opinions scores the Primary School Teachers and the District Teacher Educators on management of all teaching activities according to Taleemi Calendar. The PSTs mean opinion score was 2.57 and the mean opinion score of District Teacher Educators was 3.27 out of 5 . The t-value was $10.727 t=10.727, p<0.001$ which is overwhelmingly significant at $p=0.001$ level of significance. The Null Hypothesis $\mathrm{H}_{0}$ was rejected that the mean opinion scores Primary School Teachers and District Teacher Educators on mentoring process does not significantly differ on the management of teaching activities according to Taleemi Calendar that mentoring process was helpful in managing all teaching activities according to the Taleemi calendar. Hence it is concluded that mentoring process helped the mentees in managing the teaching activities according to Taleemi Calendar.

2. The difference between the mean opinion scores the Primary School Teachers and the District Teacher Educators was significantly observed on the management of teaching activities in a realistic way. The data showed that the respondents Primary School Teachers was mean opinion score was 3.04 and the District Teacher Educators was 3.00. The t-value was $1.175 \mathrm{t}=1.175, p>0.05$ which was not significant at $p=0.05$ level of significance. The Null Hypothesis Ho3 "the mean opinion scores PSTs and DTEs on mentoring process does not significantly differ on the management of teaching activities according to Taleemi Calendar" was not rejected. This showed that both groups of respondents Primary School Teacher and District Teacher Educators were in favorable in their opinions that mentoring process was helpful in managing teaching activities for the educational year in a realistic way.

3. The data reflected that the respondents the Primary School Teachers mean opinion score was 3.09 and the respondents District Teacher Educators mean opinion score was 3.07. The calculated t-value was 1.832 which was not significant at $\mathrm{p}=0.05$ level of significance. Hence, the Null Hypothesis Ho3 "the mean opinion scores PSTs and DTEs on mentoring process does not significantly differ on the management of teaching activities according to Taleemi Calendar" could not be rejected. This explained both groups of respondents PSTs and DTEs led favorable opinions towards the rigorously use of Taleemi Calendar.

4. The respondents Primary School Teachers mean opinion score was 4.55 and the District Teacher Educators 
mean opinion score was 4.12 that mentoring process helped in covering the backlogs of unseen days of an educational year. The t-value $3.193 t=3.193, p<0.01$ which was highly significant at $p=0.01$ level of significance. Hence, the Null Hypothesis $\mathrm{H}_{03}$ "the mean opinion scores PSTs and DTEs on mentoring process does not significantly differ on the management of teaching activities according to Taleemi Calendar" was rejected. This indicated that PSTs and DTEs differed in their opinions that mentoring process helped the in covering the backlogs of unseen days in an educational year.

5. The analyzed data showed that respondents the Primary School Teachers mean opinion score was 3.29 and the mean opinion score of the District Teacher Educators was 3.07. The calculated t-value was $0.386 \mathrm{t}=0.386$, $p>0.05$ which is not significant at $p=0.05$ level of significance. Hence, the Null Hypothesis Ho3 "the mean opinion scores PSTs and DTEs on mentoring process does not significantly differ on the management of teaching activities according to Taleemi Calendar" was not rejected. These showed that both groups of respondents PSTs and DTEs do not differed significantly and were in favorable opinions with the statement that mentoring was not helpful in achieving the pre-set targets well before time.

6. The mean opinion score of Primary School Teachers was 2.90 and District Teacher Educators mean score was 3.22 on the management of leaves or absent days. The calculated t-value was $2.870, t=2.870, p<0.01$ which was significant at $\mathrm{p}=0.01$ level of significance. The Null Hypothesis $\mathrm{H}_{03}$ "the mean opinion scores PSTs and DTEs on mentoring process does not significantly differ on the management of teaching activities according to Taleemi Calendar" was rejected. This depicted that the respondents PSTs and DTEs differed significantly in their opinions that mentoring process helped the mentees in managing the leaves or absent days of an educational year. Hence it is concluded that mentoring process was found reliable in the professional development of the Primary School Teacher as the mentoring process was helpful for the mentees in managing the leaves and absent days of an educational year.

7. The Primary School Teachers mean opinion score was 3.56 and the District Teacher Educators mean opinion score was 3.24 that mentoring process provides regular feedback that contributes towards professional development of Primary School Teachers. The calculated t-value was $0.385, t=0.385, p>0.05$ which was not significant at $p=0.05$ and the Null Hypothesis $\mathrm{H}_{03}$ "the mean opinion scores PSTs and DTEs on mentoring process does not significantly differ on the management of teaching activities according to Taleemi Calendar" could not be rejected. This depicted that both groups of the respondents PSTs and DTEs were in favorable opinions that mentoring process has provided regular feedback to the mentees which contributes towards their professional development of the Primary School Teachers.

8. The mean difference between the mean opinion scores of the Primary School Teachers and District Teacher Educators in decreasing the professional stress of the Primary School Teachers. The analyzed data give way that the respondents PSTs mean opinion score was 2.96 and the DTEs mean opinion score was 2.87. The tvalue 1.966 was significant at $p=0.05$ and the Null Hypothesis $\mathrm{H}_{03}$ was rejected that "the mean opinion scores PSTs and DTEs on mentoring process does not significantly differ on the management of teaching activities according to Taleemi Calendar". This exposed that PSTs and DTEs differed in their opinions on the statement that mentoring decreased the professional stress of the Primary School Teachers.

\section{Qualitative Data Analysis}

This part of the analysis deals with the qualitative portion of the study. As this study formed on mixed methods paradigm containing two major procedures of qualitative and quantitative i.e. QUAL \& QUAN employed. This mixed method mixed method research is an intentional use of more than one method or methodologies in the present research paper. The researcher apprehended individual as well as group interviews with the mentees i.e. Primary School Teachers (PSTs) and with mentors i.e. the District Teacher Educators (DTEs).

\subsection{Analysis of the Interviews Primary School Teacher (PSTs)}

The total number of the Primary School Teachers respondents were 38 who's the interview was conducted. The details of analysis on eight mentoring areas; 1) are given in the below mentioned graphs:- 
Nodes compared by number of items coded

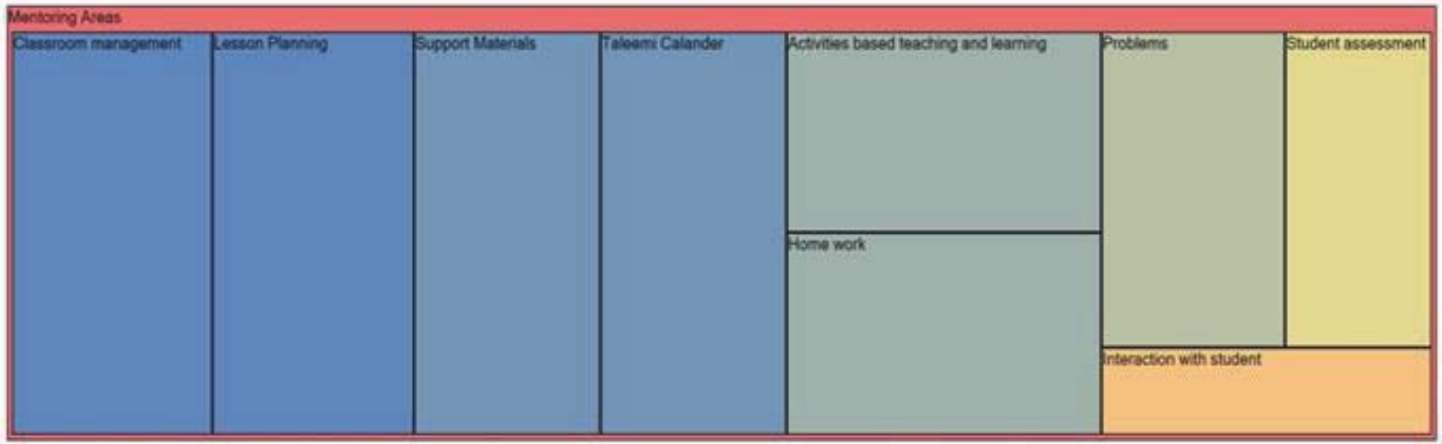

Graph 1: Tree Map of the Opinions of Primary School Teachers on Eight Mentoring Areas

The above mentioned tree map shows the difference in the responses on the responses of Primary School Teachers on eight Mentoring Areas. The diagram reflected that respondents lay stress on the, i) Classroom Management, ii) Lesson Planning, iii) Used of Support Material, iv) Taleemi Calendar, v) Activities Based Teaching \& Learning and vi) Home Work. The subsequent used mentoring areas were; i) Classroom Management, ii) Lesson Planning, iii) use of Taleemi Calendar i.e. Education Calendar. All the PSTs respondents reflected different responses on the use of Taleemi Calendar in the mentoring process under umbrella of Continue Professional Development of the Primary School Teachers. One of the PST respondents narrated that "mentoring process was helpful in removing the learning difficulties which the teacher faced in their daily teaching". Another Primary School Teacher said that "mentor makes me able to complete my syllabus before the end of academic session".

Another PST respondent spoke that "Taleemi Calendar is a set of instructions which defines the landmark dates that drive much of the day-to-day activities of schools. The present mentoring process enabled the Primary School Teachers to use the Taleemi Calendar with approach that contains cancel, withdrawal, and drops deadlines along with other attraction dates depending on the Student Learning Outcomes (SLOs). It has promoted all of the business of teaching processes such as class enrollment, statistical reporting and tuition refunds".

\subsection{Analysis of the District Teacher Educators (DTEs)}

Nodes compared by number of items coded

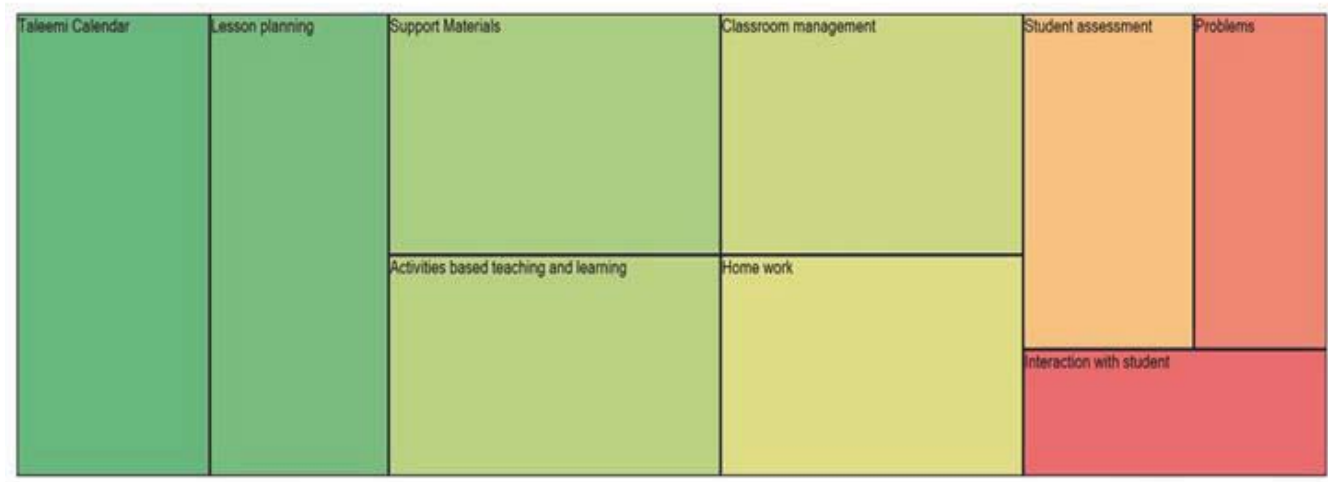

Graph 2: Tree Map of the Opinions of DTEs on Eight Mentoring Areas

The above mentioned figure shows the Tree Diagram on eight mentoring areas. The diagram reflected that the respondents laid stress on the, i) Classroom management, ii) Lesson Planning, iii) Used of Support Material, iv) Taleemi Calendar, iv) Activities Based Teaching and Learning, viii) Home work. The respondent subsequently focused on the mentoring areas; i) Taleemi Calendar, ii) Lesson Planning and iv) Use of Support Material.

One of the DTE respondent said that the objective of the present mentoring process is to establish trusting relationships with accountability and responsibility between mentors and mentees. A Taleemi Calendar is essential for 
chronology, regular divisions periods and for the study of date events. Mentoring process has enlighten the ways to the teachers for the division of extended periods such as days, months, or years, and arranging these divisions in a definite regulate order. It is also vital for any classroom activity that leads to measure period's business of Primary School Teachers.

Another DTE respondent said that mentoring process helps in defining clear learning objectives in implementing new instructional strategies. It is also helpful in locating subject area resources and selecting the right methodologies to meet learning objectives. The mentors help in creating rubrics and other assessment tools for project-based learning and assessing their skills and planning their professional development.

\section{Conclusions}

1. Taleemi Calendar was available at majority of the professional development centers. In view of the District Teacher Educators mentoring helped in managing teaching activities according to the Taleemi Calendar and most of the respondents Primary School Teachers were of same view. There was favorable opinion difference between Primary School Teachers and District Teacher Educators that mentoring helped in managing all the teaching activities according to the Taleemi Calendar.

2. Majority of the Primary School Teachers and District Teacher Educators respondents' disagreed that mentoring helped mentoring helped the teachers to manage the teaching activities for the educational year in a realistic way. The opinion difference of the PSTs\& DTEs was not favorable that mentoring helped to manage teaching activities for the educational year in a realistic way.

3. Most of the Primary School Teachers and District Teacher Educators were agreed that mentoring process was helpful to use Taleemi Calendar rigorously.

4. Majority of the Primary School Teachers and District Teacher Educators agreed that mentoring process helped them out to cover the backlogs of unseen days in an education year. However, a notable difference in the opinion of the Primary School Teachers and District Teacher Educators was observed that mentoring process helped that mentees to cover backlogs of the unseen days of the educational year.

5. Most of the respondents agreed that mentor helped that mentees to set and achieve their per-set target. Researcher observed a significant difference of opinion among the responses of PSTs \& DTEs.

6. Most of the Primary School Teachers and District Teacher Educators disagreed that mentor helped the mentees to manage the leave or absent days of the educational year.

7. Most of the Primary School Teachers and District Teacher Educators were of the view mentoring process provided the regular feedback which contributed towards their professional development..

8. Most of the Primary School Teachers and District Teacher Educators thought that mentoring process decreased the professional stress of the mentees. PSTs \& DTEs differed in their opinion that mentoring decreased the professional stress of the mentees.

\section{Discussions}

The study in hand covered the effects of mentoring process on the professional development of Primary School Teachers only one area "Taleemi Calendar" among the eight mentoring areas of mentoring. These areas are: 1) Taleemi Calendar, i.e. Educational Calendar, 2) Lesson Planning, 3) Activity Based Teaching and Learning, 4) Use of Support Material, 5) Interaction with Students, 6) Classroom Management, 7) Student Assessment and 8) Home Work. Due to different reasons the study in hand was delimited only on the mentoring area "Taleemi Calendar". The overall mean opinion of Primary School Teachers and District Teacher Educators differed on this mentoring area which reflected that mentoring process has effected significantly on the professional development of the Primary School Teachers.

This section of the study deals with the comparisons of the study results with pertinent prior research studies conducted in same field. The results of the Sheri (2012) study revealed that mentoring program was helpful for the professional development of the teachers and it has bridged the professional development gaps in the particulars area to the target group. Similarly, the results of this study in hand exposed that mentoring process was contributing towards the professional development of the Primary School Teachers.

The study conducted by Bresnahan (2011) depicted that mentoring had positive effects significantly and enhanced the communication skills of the mentees. This study also showed that mentoring process has improved the communication skills and helped the teachers in communicating effectively with students which showed the way towards the professional development of the Primary School Teachers. 
The study of Jaja 2010 conducted showed that new teachers and mentors were of same opinion that mentoring has enhanced their professional growth towards the objectives of this program. The result of this study supported to the results Jaja's study that professional development skills of the Primary School Teachers enhanced through the mentoring process. The study conducted by the Gardiner 2008 also revealed that mentoring programme benefited the junior teachers but the senior teachers were not positively influenced by mentoring activities. The results of this study are not in line with Gardiner's study because mentoring programme contributed towards professional development of the Primary School Teachers. It may however be noted that Gardiner's study was focused on public sector schools of junior level. The researcher in the referred study emphasized on the informal and online mentoring while, the present study focused on formal and on the job. Need based mentoring programmes may be designed to help the mentees in the managing the teaching activities in a realistic and comprehensive way. The Directorate of Staff Development may evolve an inclusive mentoring model for professional development of secondary school teachers. The Taleemi Calendar should be revised focusing on the ground realities so that it may enable the mentees to manage the teaching activities in a realistic and systematic way throughout the educational year. DTEs ought to include student's learning outcomes in mentoring process. English language learning was one of the key problems in every level of education in Pakistan. English language was also reviewed a as problem in the mentoring process. English language labs may be set-up at cluster centers to launch English language courses for teachers and DTES.

\section{References}

Allen, G. \& Day, J. (2002). Mentorship: A Feminist Critique of Current Research, Journal of Advanced Nursing Education, Vol. 23, No. 5, pp.1242-1250.

Anderson, J. (2012). How Newcomers use Role Models in Organizational Socialization, Journal of Workplace Learning, Vol. 2, No. 1, pp. 150-155

Bey, Theresa M. and Holmes, C. (1992) Mentoring Contemporary Principles and Issues. Reston, VA: Association of Teacher Educators.

Boyle Single, \& Muller, C. B. (2003). Building a better bridge: Testing e-training to improve e- mentoring programs for diversity in higher education. Mentoring \& Tutoring, 11 1, 67-78.

Bresnahan, L. (2011). Mentoring as an Educative Function: Professional Development Experiences Mixed Methods Study, PhD Dissertation.

Daresh, J. C. (2010). A practical guide for administrative mentoring. Thousand Oaks, CA: Corwin Press, Inc.

Darwin, A. (2000). Critical Reflections on Mentoring in Work Place Settings. Adult Education Quarterly, Vol. 51 No.3, pp. 195-199.

Donaldson, et. al.(2005). Longitudinal Examination of Mentoring Relationships on Citizenship Behavior: International Journal of Career and Professional Development, Vol. 26 No. 7, pp. 233-249.

Donaldson, S. I., Ensher, E. A., \& Grant-Vallone, E. J. (2000). Longitudinal examination of mentoring relationships on organizational commitment and citizenship behavior. Journal of Career Development, 26, 233-249.

Donaldson, S. I., et.al. (2003). Longitudinal Examination of Mentoring Relationships on Organizational Commitment and Citizenship Behavior. Journal of Career and Professional Development, Vol. 26 No. 6, pp. 239-246.

DSD (2011). District Teacher Educator DTE Guide Book, Professional Development for Quality Learning: Directorate of Staff Development, Lahore.

Faure, S. (2000). Introduction to mentoring: IM/IT community. Retrieved November 11, 2007 from the World Wide Web: http://www.ciodpi.gc.ca/orobgc/devprog/mentor/2000-09/mentoring/mentoring_e.pdf

Foster, W. \& Clark, M. (2011). Online Advance Leadership; Faculty Mentoring in Higher Education:

Gardiner, C.E. 2008. Mentoring: Towards an Improved Professional Friendship. A Mixed Study.

Glasser (2009). Mentoring \& engagement: Sustaining organizational success. Journal of Social Learning, Vol. 1, No. 1, pp. 15-25

Gless, D. (2006). Mentoring Research: A Review and Dynamic Process Model. Research in Personnel and Human Resources Management, Vol. 22, pp. 39-124.

Goodwin, D. (2006). Everyone Needs A Mentor. The Science Teachers Mentoring. Vol. 63, No.6, pp.55-59.

Govt. of Punjab (2007). Continuous Professional Development Framework for Primary School Teachers. Professional Development for Quality Learning. DSD, Lahore.

Govt. of Punjab (2011) Continuous Professional Development Framework for Primary School Teachers, Professional Development for Quality Learning. Directorate of Staff Development. Lahore.

Govt. of Punjab. (2007) Continuous Professional Development Framework for Primary School Teachers. Professional Development for Quality Learning. DSD, Lahore.

Govt. of Punjab. (2009) Final Report on Quality Assurance of Teacher Training programmes, Directorate of Staff Development Lahore, Punjab.

Govt. of Punjab. (2012). Continuous Professional Development Framework for Primary School Teachers, Professional Development for Quality Learning. Directorate of Staff Development. Lahore.

Hall, D. T. (2008). Mentoring for Careers and Professional Development for the Organizations. Thousand Oaks, CA: Sage Publications.

Huwe, J. M. (2003). Toward a Typology of Mentorship Dysfunction in Graduate Schools. Psychotherapy: Theory, Research, Practice in 
Teaching, Vol.39, pp.44-55.

Jaja, B. 2010. Evaluation of the Impact of Effective Mentoring on Teacher Retention: Mixed method Approach.

Johnson, M. (2007). Diversified mentoring relationships in organizations: A power perspective. Academy of Management Review, 222, $482-521$.

Kasprisin, C. A., Boyle Single, P., Single, R. M., \& Muller, C. B. (2003). Building a better bridge: Testing e-training to improve ementoring programs for diversity in higher education. Mentoring \& Tutoring, 11 1, 67-78.

Kasprisin, et. al. (2003). Testing E-training to improve E-Mentoring Programmes for Diversity in Higher. Me Building a Better Bridge: Mentoring \& Tutoring, Vol. 17 No.1, pp. 69-75.

Kram, K. E. (1983). Phases of the Mentoring Relationship. Academy of Management Journal, Mentoring \& Tutoring, Vol. 18 No.1, pp. 60-65.

Lewis, J. (2004). Cross-Cultural Connections: Mentoring Programs Can Bridge Gaps Between Disparate Groups

Little, J. (2010). A Leader's Guide to Mentor Training. Far West Laboratory for Educational Research and Development. Enduring Research and Development Community.

McFarlin, D. B. (2010). Perceptions of Mentor Roles across the Gender Mentoring Relationships. Journal of Vocational Behavior, Vol. 37, No. 2, pp. 321-339

Miller, L. (2004). Teacher Leadership; San Francisco: Jossey Bass, Inc.

Murphy et,al. (2005). Gender, Ethnicity, Development, and Risk: Mentoring And The Consideration Of Individual Differences. Journal of Psychology and Social Sciences, Vol. 34, No. 6, pp. 765-779.

Murray, M. (2007). The Myths and Magic of Mentoring; Leaders Helping Leaders; San Francisco: Jossey-Bass John \& Sons, Inc.

Noe, R. (2008). Women and Mentoring: A Review and Research Agenda. Academy of Educational Management, 130, pp. 69-75.

Odell, S \& Huling, L. (2010). Implications for Teacher Induction and Mentoring Programmes. Journal of Teacher Education: Research on learning to teach, EBSCO, Publishing.

Packard, D. (2002). Further investigation of protégés' negative mentoring experiences: Patterns and outcomes. Group \& Organization Management, 274, 456-479.

Ragins, B. R. (2009). A Study on the Effects of Sex and Gender Role into the Investigation on Mentorship In Male Dominated Occupations. Journal of Vocational Behavior, Vol.41, No. 1, pp. 250-261.

Sheri, A. (2012) Mentoring Functions within the American Council on Education ACE Fellows Leadership Development Program: A Mixed Methods Study.

Williams, T. C. (2008). To Create Effective Mentoring Relationships for the Teachers ,A Strategy for the Mentor and Mentee Success. Intervention in Schools and Clinics. 